\title{
Communication
}

\section{Sustainability in Near-shore Marine Systems: Promoting Natural Resilience}

\author{
Laura J. Falkenberg, Owen W. Burnell, Sean D. Connell and Bayden D. Russell * \\ Southern Seas Ecology Laboratories, School of Earth \& Environmental Sciences, University of \\ Adelaide, DX650 418, South Australia, 5005, Australia; E-Mails: laura.falkenberg@adelaide.edu.au \\ (L.J.F.); owen.burnell@adelaide.edu.au (O.W.B.); sean.connell@ adelaide.edu.au (S.D.C.) \\ * Author to whom correspondence should be addressed; E-Mail: bayden.russell@adelaide.edu.au; \\ Tel.: +61-8-8303-6587; Fax: +618-8303-6224.
}

Received: 1 July 2010; in revised form: 6 August 2010 / Accepted: 13 August 2010 /

Published: 16 August 2010

\begin{abstract}
Accumulation of atmospheric $\mathrm{CO}_{2}$ is increasing the temperature and concentration of $\mathrm{CO}_{2}$ in near-shore marine systems. These changes are occurring concurrently with increasing alterations to local conditions, including nutrient pollution and exploitation of selected biota. While the body of evidence for the negative effects of climate change is rapidly increasing, there is still only limited recognition that it may combine with local stressors to accelerate degradation. By recognizing such synergies, however, it may be possible to actively manage and improve local conditions to ameliorate the effects of climate change in the medium-term (e.g., by reducing nutrient pollution or restoring populations of herbivores). Ultimately, however, the most effective way to increase the sustainability of near-shore marine systems into the future will be to decrease our reliance on carbon-based sources of energy to reduce the negative effects of climate change.
\end{abstract}

Keywords: ecosystem shift; climate change; carbon dioxide; algae; amelioration

\section{Introduction}

As the human population has grown, so too has the extent and rate at which the environment is modified [1]. While it has long been recognized that human activities directly alter local-scale processes, such as changes to primary productivity through nutrient-pollution or its consumption 
through fishing of foragers [2-4], it is only recently that global-scale influences have started to receive recognition $[5,6]$. We now recognize that human activity is driving unprecedented change to climate beyond that attributable to natural variation [7-9]. While the body of evidence for the negative effects of climate change on natural systems is rapidly increasing, there is still only limited understanding of how multiple stressors, such as increasing $\mathrm{CO}_{2}$ and temperature, may combine to accelerate degradation [10-13]. More worrying, however, is that the impact of climate change will manifest at local scales, and as such, will also interact with local stressors that have been degrading the environment for decades, potentially accelerating change to natural systems.

\section{Synergistic Effects and Accelerated Degradation}

The oceans currently absorb $\sim 30 \%$ of the $\mathrm{CO}_{2}$ emitted into the atmosphere. It is now well established that the resulting reduction in $\mathrm{pH}$ (or ocean acidification) has negative effects on calcifying organisms [14-18]. An important recognition, however, is that in marine systems multiple climate parameters (e.g., temperature and $\mathrm{pH}$ ) are inherently linked to one another via atmospheric $\mathrm{CO}_{2}$ concentration $[19,20]$, and may create complex outcomes which cannot be predicted through studying variables independently $[13,21,22]$.

Most research into the effects of climate change on marine systems has considered acidification or temperature in isolation and there is a lack of knowledge about the extent of these interactions $[23,24]$. The few studies that have focussed on the interactions between these two parameters have demonstrated conflicting responses, showing possibilities of both synergistic negative effects on organisms [11,12] and others where the effects are not of a multiplicative nature [25]. Importantly, while organisms may show some resistance to independent stressors, their sensitivity is often altered under the concurrent application of multiple changes, resulting in effects of a larger magnitude than anticipated from the study of independent stressors [11-13,22]. Further, there is recent evidence that combinations of climate factors, such as elevated $\mathrm{CO}_{2}$ and temperature, may have synergistic positive effects on some non-calcareous algae which facilitate ecosystem shifts, thus producing a negative ecological outcome [10].

Of even greater concern is how changing climates will combine with local environmental impacts. Numerous stressors, particularly nutrient pollution and exploitation of selected biota, have resulted from human activities and produced environmental conditions distinct from those experienced at any other time in history [26]. As the effects of climate change will manifest at similar scales to these local stressors, it is likely that they will combine to alter conditions that maintain system function through amplifying feedbacks, compounding effects and synergies [27,28]. For example, in temperate marine waters canopies of algae form forests analogous to tropical rainforests. These canopies are a foundation for marine systems, providing structure that enables stabilization of physical environments, survival of associated species and economic benefit for human societies [29,30]. On many coasts of the world, however, these canopies are being replaced by small filamentous algal turfs [31-33], causing massive loss of biodiversity and ecological function. This current decline is being driven by elevated nutrients from land-derived sources [34-36]. Furthermore, it has only recently been recognized that increasing $\left[\mathrm{CO}_{2}\right]$ may increase the productivity of non-calcareous algae, particularly the opportunistic species which facilitate system shifts, suggesting that the decline of algal canopies 
will be accelerated into the future as local nutrient pollution interacts with increasing $\left[\mathrm{CO}_{2}\right]$ to increase the abundance of turf-forming algal species which inhibit the recovery of algal forests [10,37].

Nutrient-driven loss of the dominant habitat forming taxa is also well documented in tropical ecosystems, where macroalgae overgrow and smother reef-building corals [38]. As with kelp dominated systems, this habitat loss is accelerated under a combination of perturbations such as increased nutrients and harvesting of herbivores [39,40]. With the increasing body of literature demonstrating the negative effects of increasing $\left[\mathrm{CO}_{2}\right]$ on corals, it is likely that the interaction between increasing $\left[\mathrm{CO}_{2}\right]$ and nutrients will cause a synergistic negative effect on coral reefs from two directions, the negative effect on corals and the positive effect on non-calcareous macroalgae. Therefore, while the study of climate stressors on individual organisms provides insights into species level responses and adaptation, an understanding of local-to-global scale interactions between multiple stressors on communities is required to identify mechanisms of increasing resilience of systems into the future.

\section{Promoting Natural System Resilience}

Current projections of climate driven change to oceanic $\mathrm{pH}$ are based primarily upon ocean physics, with the biological components of these predictions currently lacking in sophistication [20]. Subsequently, the current understanding of the potential for natural biological interactions to provide both regional and global resilience to ocean acidification remains limited. Increasing $\mathrm{CO}_{2}$ and the associated reduction in $\mathrm{pH}$ is influenced by the photosynthesis and respiration of marine organisms [18,41-43]. For example, diurnal pH fluctuations in coastal sub-tidal zones caused by photosynthesis and respiration can be in the range of 0.2-0.3 units [44]. However, it is the very cause of this variation that may ameliorate some of the negative effects of climate change; it has been predicted that future $\mathrm{CO}_{2}$ may enhance the productivity of marine plants and potentially some non-calcifying algae [24,45-47]. Implementing conservation measures to protect large habitat-forming algae and seagrasses (c.f. algal turfs which reduce habitat complexity) could allow this adaptive capacity to moderate ocean acidification and buffer against some of the negative effects associated with increased $\left[\mathrm{CO}_{2}\right]$. While this buffering effect is likely to provide global benefits via increased carbon sequestration, additional local actions to maintain biomass of photosynthetic organisms in systems (e.g., kelp forests or seagrass meadows) may help decrease the effects of elevated $\mathrm{CO}_{2}$ within these localities.

Another management tool to enhance the resilience of systems to climate change would be to remove the potential for synergies between climate change and local conditions that have been altered by human activities. The presence of herbivores can moderate the effect of local pollution (i.e., elevated nutrients) through consumption of bloom-forming macroalgae that drive ecosystem shifts at the expense of complex habitat-formers [40,48-51]. There is also evidence that the presence of herbivores may increase the resilience of systems to climate-related stressors, as seen with the recovery of coral reefs from bleaching events [52]. Therefore, protection of herbivores from harvesting, such as through the establishment of Marine Protected Areas, could increase the resilience of natural systems to both local and global stressors.

This moderating effect of herbivory can, however, be overwhelmed by longer-term eutrophication events $[48,50,53]$. Further, it can be reasonably predicted that ocean acidification may disrupt the 
feeding biology of some herbivores [54,55], restricting their ability to effectively control the nutrient or climate-enhanced growth of algae. Therefore, reducing the potential for synergies between local conditions and climate change may only be possible by reducing the nutrient load entering marine waters from terrestrial sources [37]. Recognition of the need to increase resilience in natural systems has lead to more proactive management of local stressors in some regions. In South Australia, local government now recognizes the global-local connections of future change, and has implemented long-term policy to upgrade wastewater treatment plants and to recapture storm-water to produce recycled water for residential and industrial use. While concerned mainly with the provision of freshwater for human use, this policy also reduces the nutrient rich discharge that has primarily contributed to phase shifts on metropolitan reefs from kelp to turf-dominated [32,34].

While recent experimental work indicates that the reduction of pollution or supporting populations of herbivores may increase resilience of near-shore marine systems [37,52], it is likely that the regional biological context will be an important consideration. In regions which have naturally eutrophic waters (e.g., upwelling zones) and strong herbivory it may be more appropriate to use Marine Protected Areas to support natural populations of herbivores. Conversely, elevated nutrients can have disproportionately large effects in regions which have oligotrophic waters and weak herbivory [56] so restricting terrestrial based sources of nutrient pollution may be more affective in maintaining system resilience under future climates. Further, regional assessments of the potential impact of climate change show that it's effects will vary geographically and that actions to ameliorate climate change will need to differ among regions [57,58]. Therefore, to maximize the effectiveness of actions to increase the resilience of natural systems to climate change, it will be necessary to identify the regional drivers of systems (e.g., nutrients $v s$. herbivory) and the likely drivers of future change (e.g., temperature $v s$. increasing $\left[\mathrm{CO}_{2}\right]$ )

What we are yet to identify is whether local mitigation measures are likely to be more effective when implemented before forecasted climates arrive [59]. Recruitment of habitat-forming species is key to ecosystem resilience [60], and both local and global perturbations tend to promote species which inhibit recruitment of habitat-forming species [31,34,40,52]. Therefore, it is likely that locations which have already undergone loss of habitats driven by anthropogenic perturbations will be less likely to recover to their "natural" state if local amelioration actions are implemented after global stressors have passed a threshold where recruitment of habitat-forming species is inhibited.

\section{Conclusions}

The anticipated synergies between local conditions and increasing temperature and $\mathrm{CO}_{2}$ have clear implications for the function of marine systems globally. In the medium-term, it may be possible to promote the resilience of natural systems by either reducing local stressors or supporting populations of organisms which will alter the effects of these stressors. Management which limits nutrient addition (i.e., stops waste water outfall) or protects herbivores from fishing (e.g., Marine Protected Areas) will restrict the growth of bloom-forming algae and possibly prevent system shifts to less desirable states, especially if such strategies are implemented in unison. Such management actions cannot, however, ameliorate the effect of negative synergies between climate factors (e.g., $\mathrm{CO}_{2}$ and temperature) and ultimately the only way to mitigate the effects of climate change is to reduce reliance on carbon-based sources of fuel [61]. This understanding is particularly important as managing global-scale changes is 
inherently difficult because their sheer magnitude requires an international effort to implement policy change and because their effects are so long-lasting, if not permanent.

\section{Acknowledgements}

Financial support for this research was provided by an ARC Linkage Grant for BDR and SDC and an ARC Future Fellowship for SDC.

\section{References}

1. Vitousek, P.M.; Mooney, H.A.; Lubchenco, J.; Melillo, J.M. Human domination of earth's ecosystems. Science 1997, 277, 494-499.

2. Hatcher, B.G.; Larkum, A.W.D. An experimental analysis of factors controlling the standing crop of the epilithic algal community on a coral reef. J. Exp. Mar. Biol. Ecol. 1983, 69, 61-84.

3. Jackson, J.B.C. What was natural in the coastal oceans? Proc. Natl. Acad. Sci. USA 2001, 98, 5411-5418.

4. McElroy, M.B.; Wofsy, S.C.; Yung, Y.L. The nitrogen cycle: Perturbations due to man and their impact on atmospheric $\mathrm{N}_{2} \mathrm{O}$ and $\mathrm{O}_{3}$. Phil. Trans. Roy. Soc. B-Biol. Sci. 1977, 277, 159-181.

5. Gillett, N.P.; Zwiers, F.W.; Weaver, A.J.; Stott, P.A. Detection of human influence on sea-level pressure. Nature 2003, 422, 292-294.

6. Karl, T.R.; Trenberth, K.E. Modern global climate change. Science 2003, 302, 1719-1723.

7. Stott, P.A.; Tett, S.F.B.; Jones, G.S.; Allen, M.R.; Ingram, W.J.; Mitchell, J.F.B. Attribution of twentieth century temperature change to natural and anthropogenic causes. Clim. Dynam. 2001, $17,1-21$.

8. Turley, C. Impacts of changing ocean chemistry in a high- $\mathrm{CO}_{2}$ world. Mineral. Mag. 2008, 72, 359-362.

9. Zachos, J.C.; Rohl, U.; Schellenberg, S.A.; Sluijs, A.; Hodell, D.A.; Kelly, D.C.; Thomas, E.; Nicolo, M.; Raffi, I.; Lourens, L.J.; McCarren, H.; Kroon, D. Rapid acidification of the ocean during the Paleocene-Eocene thermal maximum. Science 2005, 308, 1611-1615.

10. Connell, S.D.; Russell, B.D. The direct effects of increasing $\mathrm{CO}_{2}$ and temperature on non-calcifying organisms: Increasing the potential for phase shifts in kelp forests. Proc. Roy. Soc. B-Biol. Sci. 2010, 277, 1409-1415.

11. Findlay, H.S.; Kendall, M.A.; Spicer, J.I.; Widdicombe, S. Post-larval development of two intertidal barnacles at elevated $\mathrm{CO}_{2}$ and temperature. Mar. Biol. 2010, 157, 725-735.

12. Martin, S.; Gattuso, J.P. Response of Mediterranean coralline algae to ocean acidification and elevated temperature. Glob. Change Biol. 2009, 15, 2089-2100.

13. Przeslawski, R.; Davis, A.R.; Benkendorff, K. Synergistic effects associated with climate change and the development of rocky shore molluscs. Glob. Change Biol. 2005, 11, 515-522.

14. Feely, R.A.; Sabine, C.L.; Lee, K.; Berelson, W.; Kleypas, J.; Fabry, V.J.; Millero, F.J. Impact of anthropogenic $\mathrm{CO}_{2}$ on the $\mathrm{CaCO}_{3}$ system in the oceans. Science 2004, 305, 362-366.

15. Gattuso, J.P.; Buddemeier, R.W. Ocean biogeochemistry-Calcification and $\mathrm{CO}_{2}$. Nature 2000, 407, 311-313. 
16. Gazeau, F.; Quiblier, C.; Jansen, J.M.; Gattuso, J.P.; Middelburg, J.J.; Heip, C.H.R. Impact of elevated $\mathrm{CO}_{2}$ on shellfish calcification. Geophys. Res. Lett. 2007, 34, doi:10.1029/2006GL028554.

17. Kleypas, J.A.; Buddemeier, R.W.; Archer, D.; Gattuso, J.P.; Langdon, C.; Opdyke, B.N. Geochemical consequences of increased atmospheric carbon dioxide on coral reefs. Science 1999, 284, 118-120.

18. Leclercq, N.; Gattuso, J.P.; Jaubert, J. $\mathrm{CO}_{2}$ partial pressure controls the calcification rate of a coral community. Glob. Change Biol. 2000, 6, 329-334.

19. Hoegh-Guldberg, O.; Mumby, P.J.; Hooten, A.J.; Steneck, R.S.; Greenfield, P.; Gomez, E.; Harvell, C.D.; Sale, P.F.; Edwards, A.J.; Caldeira, K.; Knowlton, N.; Eakin, C.M.; Iglesias-Prieto, R.; Muthiga, N.; Bradbury, R.H.; Dubi, A.; Hatziolos, M.E. Coral reefs under rapid climate change and ocean acidification. Science 2007, 318, 1737-1742.

20. Kleypas, J.; Feely, R.A.; Fabry, V.J.; Langdon, C.; Sabine, C.L.; Robbins, L.L. Impacts of Ocean Acidification on Coral Reefs and Other Marine Calcifiers: A Guide for Future Research. In Proceedings of the Workshop on the Impacts of Increasing Atmospheric $\mathrm{CO}_{2}$ on Coral Reefs and Other Marine Calcifiers, St Petersburg, FL, USA, 18-20 April 2005.

21. Bezemer, T.M.; Knight, K.J. Unpredictable responses of garden snail (Helix aspersa) populations to climate change. Acta Oecol. 2001, 22, 201-208.

22. Reynaud, S.; Leclercq, N.; Romaine-Lioud, S.; Ferrier-Pages, C.; Jaubert, J.; Gattuso, J.P. Interacting effects of $\mathrm{CO}_{2}$ partial pressure and temperature on photosynthesis and calcification in a scleractinian coral. Glob. Change Biol. 2003, 9, 1660-1668.

23. Fine, M.; Franklin, L.A. Climate change in marine ecosystems. In Marine Ecology; Connell, S.D., Gillanders, B.M., Eds.; Oxford University Press: Melbourne, VIC, Australia, 2007; pp. 595-612.

24. Guinotte, J.M.; Fabry, V.J. Ocean acidification and its potential effects on marine ecosystems. Ann. N. Y. Acad. Sci. 2008, 1134, 320-342.

25. Langdon, C.; Atkinson, M.J. Effect of elevated $\mathrm{pCO}_{2}$ on photosynthesis and calcification of corals and interactions with seasonal change in temperature/irradiance and nutrient enrichment. J. Geophys. Res. 2005, 110, doi:10.1029/2004JC002576.

26. Lotze, H.K.; Worm, B. Complex interactions of climatic and ecological controls on macroalgal recruitment. Limnol. Oceanogr. 2002, 47, 1734-1741.

27. Nystrom, M.; Folke, C.; Moberg, F. Coral reef disturbance and resilience in a human-dominated environment. Trends Ecol. Evol. 2000, 15, 413-417.

28. Paine, R.T.; Tegner, M.J.; Johnson, E.A. Compounded perturbations yield ecological surprises. Ecosystems 1998, 1, 535-545.

29. Steneck, R.S.; Graham, M.H.; Bourque, B.J.; Corbett, D.; Erlandson, J.M.; Estes, J.A.; Tegner, M.J. Kelp forest ecosystems: Biodiversity, stability, resilience and future. Environ. Conserv. 2002, 29, 436-459.

30. Tegner, M.J.; Dayton, P.K. Ecosystem effects of fishing in kelp forest communities. ICES J. Mar. Sci. 2000, 57, 579-589.

31. Airoldi, L.; Beck, M.W. Loss, status and trends for coastal marine habitats of Europe. Oceanogr. Mar. Biol. Ann. Rev. 2007, 45, 345-405. 
32. Connell, S.D.; Russell, B.D.; Turner, D.J.; Shepherd, S.A.; Kildea, T.; Miller, D.; Airoldi, L.; Cheshire, A. Recovering a lost baseline: Missing kelp forests from a metropolitan coast. Mar. Ecol. Prog. Ser. 2008, 360, 63-72.

33. Eriksson, B.K.; Johansson, G.; Snoeijs, P. Long-term changes in the macroalgal vegetation of the inner Gullmar Fjord, Swedish Skagerrak coast. J. Phycol. 2002, 38, 284-296.

34. Gorman, D.; Russell, B.D.; Connell, S.D. Land-to-sea connectivity: Linking human-derived terrestrial subsidies to subtidal habitat-change on open rocky coasts. Ecol. Appl. 2009, 19, 1114-1126.

35. Kraufvelin, P.; Christie, H.; Olsen, M. Littoral macrofauna (secondary) responses to experimental nutrient addition to rocky shore mesocosms and a coastal lagoon. Hydrobiologia 2002, 484, 149-166.

36. Pedersen, M.; Snoeijs, P. Patterns of macroalgal diversity, community composition and long-term changes along the Swedish west coast. Hydrobiologia 2001, 459, 83-102.

37. Russell, B.D.; Thompson, J.I.; Falkenberg, L.J.; Connell, S.D. Synergistic effects of climate change and local stressors: $\mathrm{CO}_{2}$ and nutrient driven change in subtidal rocky habitats. Glob. Change Biol. 2009, 15, 2153-2162.

38. Fabricius, K.E. Effects of terrestrial runoff on the ecology of corals and coral reefs: Review and synthesis. Mar. Poll. Bull. 2005, 50, 125-146.

39. Bellwood, D.R.; Hughes, T.P.; Folke, C.; Nystrom, M. Confronting the coral reef crisis. Nature 2004, 429, 827-833.

40. Smith, J.E.; Hunter, C.L.; Smith, C.M. The effects of top-down versus bottom-up control on benthic coral reef community structure. Oecologia 2010, 163, 497-507.

41. Gao, K.; Aruga, Y.; Asada, K.; Ishihara, T.; Akano, T.; Kiyohara, M. Enhanced growth of the red alga porphyra-yezoensis ueda in high $\mathrm{CO}_{2}$ concentrations. J. Appl. Phycol. 1991, 3, 355-362.

42. Gao, K.; McKinley, K.R. Use of macroalgae for marine biomass production and $\mathrm{CO}_{2}$ remediation: A review. J. Appl. Phycol. 1994, 6, 45-60.

43. Shirayama, Y.; Thornton, $\mathrm{H}$. Effect of increased atmospheric $\mathrm{CO}_{2}$ on shallow water marine benthos. J. Geophys. Res. 2005, 110, doi:10.1029/2004JC002618.

44. Yates, K.K.; Dufore, C.; Smiley, N.; Jackson, C.; Halley, R.B. Diurnal variation of oxygen and carbonate system parameters in Tampa Bay and Florida Bay. Mar. Chem. 2007, 104, 110-124.

45. Beardall, J.; Beer, S.; Raven, J.A. Biodiversity of marine plants in an era of climate change: Some predictions based on physiological performance. Bot. Mar. 1998, 41, 113-123.

46. Short, F.T.; Neckles, H.A. The effects of global climate change on seagrasses. Aquat. Bot. 1999, 63, 169-196.

47. Duarte, C.M. The future of seagrass meadows. Environ. Conserv. 2002, 29, 192-206.

48. Lotze, H.K.; Worm, B.; Sommer, U. Strong bottom-up and top-down control of early life stages of macroalgae. Limnol. Oceanogr. 2001, 46, 749-757.

49. Miller, M.W.; Hay, M.E. Coral-seaweed-grazer-nutrient interactions on temperate reefs. Ecol. Monogr. 1996, 66, 323-344.

50. Russell, B.D.; Connell, S.D. Response of grazers to sudden nutrient pulses in oligotrophic versus eutrophic conditions. Mar. Ecol. Prog. Ser. 2007, 349, 73-80. 
51. Worm, B.; Lotze, H.K. Effects of eutrophication, grazing, and algal blooms on rocky shores. Limnol. Oceanogr. 2006, 51, 569-579.

52. Hughes, T.P.; Rodrigues, M.J.; Bellwood, D.R.; Ceccarelli, D.; Hoegh-Guldberg, O.; McCook, L.; Moltschaniwskyj, N.; Pratchett, M.S.; Steneck, R.S.; Willis, B. Phase shifts, herbivory, and the resilience of coral reefs to climate change. Curr. Biol. 2007, 17, 360-365.

53. Eriksson, B.K.; Rubach, A.; Hillebrand, H. Dominance by a canopy forming seaweed modifies resource and consumer control of bloom-forming macroalgae. Oikos 2007, 116, 1211-1219.

54. Bibby, R.; Cleall-Harding, P.; Rundle, S.; Widdicombe, S.; Spicer, J. Ocean acidification disrupts induced defences in the intertidal gastropod Littorina littorea. Biol. Lett. 2007, 3, 699-701.

55. Marchant, H.K.; Calosi, P.; Spicer, J.I. Short-term exposure to hypercapnia does not compromise feeding, acid-base balance or respiration of Patella vulgata but surprisingly is accompanied by radula damage. J. Mar. Biol. Assn. UK 2010, June, doi:10.1017/S0025315410000457.

56. Russell, B.D.; Elsdon, T.E.; Gillanders, B.M.; Connell, S.D. Nutrients increase epiphyte loads: Broad scale observations and an experimental assessment. Mar. Biol. 2005, 147, 551-558.

57. Poloczanska, E.S.; Hobday, A.J.; Richardson, A.J. Report Card of Marine Climate Change for Australia; Detailed Scientific Assessment; NCCARF Publication: Southport, QLD, Australia, 2009.

58. Baxter, J.M.; Buckley, P.J.; Wallace, C.J. Marine Climate Change Impacts Annual Report Card 2010-2011; MCCIP: Lowestoft, UK, 2010; p. 12.

59. Mignone, B.K.; Socolow, R.H.; Sarmiento, J.L.; Oppenheimer, M. Atmospheric stabilization and the timing of carbon mitigation. Clim. Change 2008, 88, 251-265.

60. Pickett, S.T.A.; White, P.S. The Ecology of Natural Disturbance and Patch Dynamics; Academic Press: San Diego, CA, USA, 1985; p. 472.

61. Russell, B.D.; Connell, S.D. Honing the geoengineering strategy. Science 2010, 327, 144-145.

(C) 2010 by the authors; licensee MDPI, Basel, Switzerland. This article is an Open Access article distributed under the terms and conditions of the Creative Commons Attribution license (http://creativecommons.org/licenses/by/3.0/). 